\title{
Incorporation of disinfectants for obtaining dental stone: microbiological and dimensional evaluation
}

\author{
Incorporação de desinfetantes para obtenção de modelos de gesso: avaliação microbiológica e dimensional \\ Patrícia Lins Azevedo do NASCIMENTO ${ }^{a \star}$, Rafael Bezerra RIBEIRO ${ }^{\text {, }}$ Cícero Romão GADÊ-NETO \\ Alexandre Henrique de Moura DIAS ${ }^{\mathrm{b}}$
}

${ }^{a}$ Faculdade de Odontologia, ASCES - Associação Caruaruense de Ensino Superior, Caruaru, PE, Brasil

${ }^{\mathrm{b}}$ Faculdade de Odontologia, UnP - Universidade Potiguar, Natal, RN, Brasil

\begin{abstract}
Resumo
Objetivo: Avaliar alteração dimensional e ação antimicrobiana de substâncias desinfetantes incorporadas durante manipulação do gesso. Material e método: In vivo - Micro-organismos foram coletados com swabs dos moldes de 30 voluntários, inoculados em Ágar BHI e incubados a $37^{\circ} \mathrm{C}$ por 24 horas. Os moldes foram vazados com gesso tipo IV, manipulados com soro fisiológico (G1), hipoclorito de sódio 1\% (G2) e clorexidina 4\% (G3) substituindo a água. Decorrida 1 hora de presa fez-se duas coletas com swabs nos modelos, incubação e leituras das placas após 24 horas. Empregaram-se os testes Kruskal-Wallis e Wilcoxon com níveis de confiança de 99\% e 95\% respectivamente. In vitro - Inocularam-se S. mutans (ATCC25175), S. sanguis (ATCC10556) e E. faecalis (ATCC29212) em Ágar Müeller Hinton, onde posicionaram-se anéis de aço preenchidos com as mesmas substâncias do estudo in vivo. Após deposição do gesso e incubação, os halos foram medidos com paquímetro digital e os dados submetidos à ANOVA e Tukey com nível de confiança de 95\%. Alteração dimensional - Com matriz metálica e moldeira perfeitamente adaptada padronizou-se eixo de inserção e força empregada para moldagem e obtenção de 30 corpos de prova em gesso tipo IV, seguindo a mesma distribuição dos grupos do estudo in vivo. Os corpos de prova foram mensurados pelo software Image Pro Plus e os dados submetidos à ANOVA e Tukey com nível de confiança de $95 \%$. Resultado: Os dados do estudo in vivo demonstraram diferença significativa entre molde e cada modelo ( $\mathrm{p}<0,001)$. No teste Wilcoxon não houve diferença significante entre grupos de modelos. In vitro- G2 apresentou maiores halos de inibição em todos micro-organismos testados em relação ao G3, mas com relação à alteração dimensional, houve diferença significante entre soluções e padrão metálico, onde G3 provocou menor alteração do que G2. Conclusão: Clorexidina $4 \%$ apresentou-se como o desinfetante mais adequado.
\end{abstract}

Descritores: Microbiologia; clorexidina; hipoclorito de sódio; modelos dentários.

\begin{abstract}
Aim: To assess dimensional change and antimicrobial activity of disinfectants substances incorporated during the dental stone manipulation. Material and method: In vivo - microorganisms were collected in alginate molds of 30 volunteers inoculated on BHI agar and incubated at $37^{\circ} \mathrm{C}$ for 24 hours. The molds were cast with type IV gypsum, manipulated with saline (G1), $1 \%$ sodium hypochlorite (G2) and $4 \%$ chlorhexidine (G3), replacing the water. After setting of plaster with 1 hour two collections on models were made. After 24 hours, the readings were performed. The Kruskal-Wallis and Wilcoxon tests with confidence interval of $99 \%$ and $95 \%$ respectively were used. In vitro - Müeller Hinton agar petri dishes were inoculated with S. mutans (ATCC25175), S. sanguis (ATCC10556) and E. faecalis (ATCC29212), over which were placed steel rings filled with the same substances of the in vivo study. After deposition of gypsum and incubation, halos were measured with a digital caliper and data were submitted to ANOVA and Tukey's test with confidence interval of 95\%. Dimensional Change - With a metallic matrix and a perfectly adapted tray, the insertion axis and force used for moulding and obtain 30 specimens in type IV gypsum were standardized, following the same distribution of the study groups in vivo. The specimens were measured by Image Pro Plus software and data were submitted to ANOVA and Tukey's test with confidence interval of $95 \%$. Result: Data from the in vivo study demonstrated a significant difference between the mold and each model $(\mathrm{p}<0.001)$. In the Wilcoxon test there was no significant difference between groups of models. At the in vitro test, G2 showed greater inhibition zones in all micro-organisms tested compared to G3, but with respect to dimensional changes, there was a significant difference between solutions and metallic standard, where G3 caused less change than G2. Conclusion: Chlorhexidine 4\% showed to be the most suitable disinfectant.
\end{abstract}

Descriptors: Microbiology; chlorhexidine; sodium hypochlorite; dental models. 


\section{INTRODUCTION}

Obtaining moulds and creating clinical casts is commonplace in dentistry, and contamination is a fact that cannot be overlooked by the professional when considering the safety of the patient and the entire team.

With the evolution of infectious and contagious pathogens, the adoption of infection control methods has come to be of paramount importance, due to the ease with which prosthetic and instrumental works become contaminated during clinical activities $^{1}$. Moulds, bite registrations, prostheses and apparatus that come into contact with the patient's oral fluids must be disinfected before being sent to a prosthetics laboratory $y^{2-4}$.

When making a dental prosthesis, several steps and materials are needed. Professionals report difficulty in carrying out biosafety procedures during this process; these difficulties may facilitate cross contamination and the spread of certain diseases, such as hepatitis (B and C), tuberculosis, acquired immunodeficiency syndrome (AIDS) and herpes. Furthermore, other normally nonpathogenic microorganisms can cause pathogenic opportunistic infections in immunocompromised persons ${ }^{5}$.

Souza et al. $^{6}$ (2001) stressed that the AIDS virus and hepatitis B are deactivated by $2 \%$ glutaraldehyde and $1 \%$ sodium hypochlorite; however, these microorganisms are more resistant and are not eliminated with $0.5 \%$ chlorhexidine. The efficacy of a disinfectant depends on sufficient contact time and on the concentration of the substance ${ }^{7}$.

Among the primary casting materials, alginate is the most widely used in dentistry and the most difficult to disinfect, due to its high capacity to lose or incorporate water, which causes the material to undergo dimensional changes ${ }^{8}$.

Plaster casts can be disinfected by spraying or dipping the cast into a disinfecting solution, by adding an antimicrobial agent to the plaster mix, or by manipulating the plaster with a disinfectant solution? .

The disinfection methods recommended in the area of prostheses are of concern to professionals due to the possible occurrence of dimensional changes ${ }^{10}$. In dentistry, it is important to select the correct disinfection method to achieve crossinfection control without causing harm ${ }^{11}$. The desired accuracy of plaster casts following disinfection is related to several factors, including the impression material, disinfectant solutions and mouldings.

Given the need for the disinfection of dental moulds and the interest in reducing the professional's working time, the current study assessed the occurrence of dimensional changes and the antimicrobial efficacy of two disinfecting solutions, $1 \%$ hypochlorite (v/v) and $4 \%$ chlorhexidine (v/v). These solutions were incorporated during the manipulation of type IV plaster as a substitute for water. The hypothesis tested in the present study was whether the incorporation of a disinfectant solution in lieu of water during plaster manipulation would facilitate decontamination without causing dimensional changes in the casts.

\section{MATERIAL AND METHOD}

This work involved a microbiological study and a study of the casts' dimensional changes. The microbiological study was subdivided into in vivo and in vitro studies.

\section{In Vivo Microbiological Study}

Three mouldings were made with partial perforated moulds in aluminium (Tecnodent, Tecnodent Indústria e Comércio Ltda, São Paulo, SP, Brazil) and alginate (Jeltrate Plus, Dentsply Indústria e Comércio Ltda, Rio de Janeiro, RJ, Brazil). These mouldings were of the anterosuperior region of the dental arch (canine to canine) of 30 volunteers, totalling 90 mouldings. Individuals who did not present any tooth elements in the anterosuperior region and those using braces were excluded from the sample. The research project was approved by the Research Ethics Committee of Potiguar University (Universidade Potiguar, UNP/RN), under registration number 151/2006.

After the moulds were obtained, they were washed in running water for 20 seconds to reproduce the clinical procedure as closely as possible. After the moulds were washed in running water, swabs soaked in sterile saline and inoculated in BHI agar culture medium (Difco ${ }^{\mathrm{TM}}$ Becton, Dickinson and Company, Sparks, MD 211152, USA) were used to obtain microorganism samples. Petri dishes were incubated in a microbiological incubator at $37^{\circ} \mathrm{C}$ for 24 hours. After this period of time, the colony forming units (CFU) were counted using a CP500 colony counter (Phoenix, Phoenix Indústria e Comércio de Equipamentos Científicos Ltda., Araraquara, SP, Brazil). The areas of the moulds selected for sampling were the buccal, lingual and incisal surfaces and the palate region and vestibule of elements 11, 12, 13, 21, 22 and 23.

After sampling, the moulds were filled with type IV plaster (Durone, Dentsply Indústria e Comércio Ltda, Rio de Janeiro, RJ, Brazil) treated with saline (ADV ${ }^{\oplus-}$ Laboratório Tayuyna Ltda, São Paulo, SP, Brazil) (G1), sodium hypochlorite 1\% (v/v) (Pharmácia Universitária, Natal, RN, Brazil) (G2) or chlorhexidine 4\% (v/v) (Pharmácia Universitária, Natal, RN, Brazil) (G3), following the ratio specified by the manufacturer.

After waiting one hour for the plaster to set, the cast was separated from the mould. A sterile swab was soaked in saline and rubbed on the plaster cast on the buccal, lingual and incisal surfaces and vestibule and palate region of teeth 11,12 and 13 . The swab was then used to inoculate BHI agar culture medium, and the dishes were incubated in a microbiological incubator at $37^{\circ} \mathrm{C}$ for 24 hours. Twenty-four hours after this first cast sampling, the number of CFU in the Petri dishes was counted.

Cast sampling was repeated in the same manner after 24 hours on the buccal, lingual and incisal surfaces and the vestibule and palate regions of teeth 21, 22 and 23. Twenty-four hours after the second sampling of plaster casts, the CFU count was performed.

To compare the data from the contaminated moulds and casts in the 1st and 2nd samplings, a Kruskal-Wallis test with a confidence level of $99 \%$ and a Dunn post test were performed. To analyse the disinfecting action of each substance, the two samples 
of each substance were compared, and a Wilcoxon test with a confidence level of $95 \%$ was used.

\section{In Vitro Microbiological Study}

Strains of Streptococcus mutans (ATCC25175), Streptococcus sanguis (ATCC10556) and Enterococcus faecalis (ATCC29212) were collected. The microorganisms were sewn onto Mueller Hinton agar medium (Difco ${ }^{\mathrm{TM}}$ Becton, Dickinson and Company, Sparks, MD 211152, USA) in triplicate.

After pre-incubating the seeded dishes for one hour, alginate was manipulated with saline according to the manufacturer's instructions, and type IV plaster was treated with saline, 1\% sodium hypochlorite (v/v) or $4 \%$ chlorhexidine (v/v). These manipulated materials were dispensed into stainless steel rings $10.5 \mathrm{~mm}$ high with a $7.4 \mathrm{~mm}$ diameter and positioned on the culture medium in the Petri dishes. These dishes were incubated in a microbiological incubator at $37^{\circ} \mathrm{C}$ for 24 hours.

After the incubation period, the inhibition halo formed by the substances was measured with the aid of a digital caliper. Two measurements were made perpendicular to each other, and the mean sizes were found; the data were analysed using an ANOVA and Tukey's test, with a confidence level of $99 \%$. The test was performed in triplicate for each microorganism.

\section{Study of the Dimensional Changes of the Casts}

The sample consisted of 30 specimens. Ten samples were evaluated for each substance; Group 1 was the saline sample, Group 2 was the $1 \%$ sodium hypochlorite (v/v) sample, and Group 3 was the $4 \%$ chlorhexidine (v/v) sample.

To form the mouldings, a matrix of stainless steel was made in the shape of a pentagon with five convex pillars, containing two perpendicular lines at its upper end. A stainless steel mould was also constructed that fit this matrix perfectly. This moulding was attached to the platform of a liner with a removable prosthesis, while the matrix was attached to a movable vertical rod by a pin on its base, which standardised the axis of insertion of the mould/ matrix (Figure 1). The standardisation of force during casting was achieved by adapting the mould, which had a "stop" generated by its own format (in the form of sloping walls) that limited the insertion depth of the matrix.

The same alginate used for the microbiological studies was used to form the mouldings, according to the proportions specified by the manufacturer. The moulds were cast with type IV plaster in the same manner as in the microbiological studies. Following the plaster setting time, the casts were stored at room temperature for 24 hours. After 24 hours, the casts were photographed and the distance between the centres of the perpendicular lines of the matrix and the casts were measured using Image Pro Plus software (Media Cybernetics, Inc., Rockville, MD, USA) (Figure 2). To determine which groups showed distortions in the metallic matrix, ANOVAs and Tukey's tests, at a 95\% confidence level, were performed for multiple comparisons of the substances.

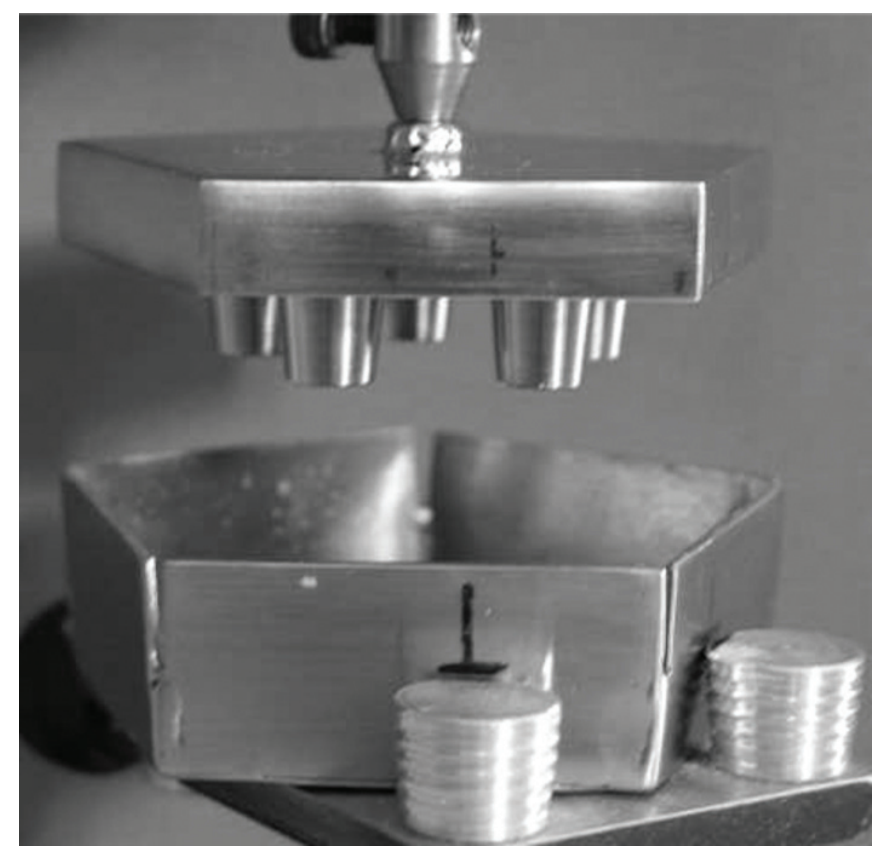

Figure 1. Moulding set/matrix positioned in the liner.

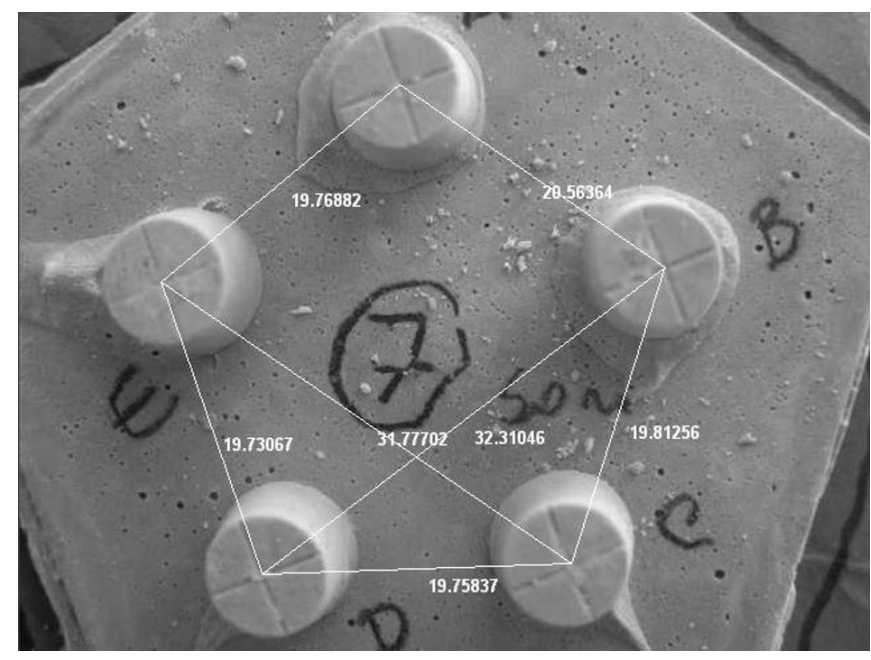

Figure 2. Plaster cast with measurements between the pillars ( $\mathrm{mm})$.

\section{RESULT}

\section{In Vivo Microbiological Study}

A statistically significant difference was observed between the moulds and the first sample of casts $(p<0.001)$; the moulds that were completely contaminated during the first cast sample showed a decrease in contamination. However, there was no significant difference in contamination between the casts of $G 1$, G2 and G3 (p > 0.05).

There was a significant difference in contamination between the moulds and the second sample of each cast $(\mathrm{p}<0.001)$, but not between the three types of casts in the second sample $(\mathrm{p}>0.05)$.

To analyse the disinfecting action of each substance, the two samples of each substance were compared, and a Wilcoxon test was performed. In Group 1, there was no statistically significant difference between the first and second sampling of casts with 
saline, $\mathrm{p}>0.05$ (0.1563). In Group 2, there was no statistically significant difference between the first and second sampling in casts with $1 \%$ sodium hypochlorite, $\mathrm{p}>0.05$ (0.2188). In the casts with chlorhexidine, it was not possible to statistically analyse the data because all of the values from the second measurement were zero.

All casts of all samples showed a statistically significant reduction in contamination in relation to the moulds, but Wilcoxon tests showed no significant difference between the casts with saline, $1 \%$ sodium hypochlorite or $4 \%$ chlorhexidine in either the first ( 1 hour) or the second ( 24 hour) samples.

\section{In Vitro Microbiological Study}

ANOVA results indicated no significant differences between groups in the microorganism variable $(\mathrm{p}=0.57)$, but indicated significant differences in the solution variable $(\mathrm{p}<0.001)$ (Figure 3).

Group 2 showed statistically significantly larger inhibition halos than Group 3 in all microorganisms tested, according to Tukey's test $(\mathrm{p}<0.001)$.

In the saline and alginate groups, there was no formation of inhibition halos; thus, these data were not analysed statistically.

\section{Study of the Dimensional Changes of the Casts}

A statistically significant difference in distortion with respect to the metallic matrix was observed between the solutions and between the solutions and the metal standard (control) $(\mathrm{p}<0.05)$ (Table 1). Group 1 showed a statistically significant mean dimensional change $(1.442 \mathrm{~mm})$. In Group 2, there was also a statistical significant mean dimensional change $(0.626 \mathrm{~mm})$. In Group 3, the mean dimensional change was $0.309 \mathrm{~mm}$ (Figure 4). The dimensional changes of the three groups were in the form of expansion, as all the means were positive.

\section{DISCUSSION}

The need to decontaminate materials that have come in contact with the blood, saliva and debris from the mouths of patients is essential in clinical dental care. Several substances and methods have been studied and are now established disinfection procedures for moulds, casts and related materials. These techniques include dipping the mould in disinfectant solution ${ }^{8,9,12}$, applying disinfectant spray over the mould ${ }^{13}$, immersing the casts ${ }^{9}$, and incorporating the disinfectant substances during the handling of the plaster ${ }^{14-17}$. In the present study, the latter technique was chosen to eliminate a step in the process of obtaining the casts, with the intention of reducing clinical practice time.

Chlorhexidine at a concentration of $4 \%$ was selected as a disinfectant because it does not have a corrosive effect ${ }^{18}$. Sodium hypochlorite at a concentration of $1 \%$ was selected for treatment of the plaster, because concentrations lower than $0.2 \%$ chlorhexidine gluconate and lower than $1 \%$ sodium hypochlorite are ineffective at decontaminating moulds ${ }^{19}$.

Alginate is a casting material that incorporates high levels of microorganisms, not only on its surface, but also in its inner layers ${ }^{1,3,4}$. This material retains two to three times more microorganisms than elastomers, and this retention is greater in dentulous than in edentulous individual $\mathrm{s}^{20}$. Alginate is, therefore,

Table 1. Means of the dimensional variations for each solution ( $\mathrm{mm}$ )

\begin{tabular}{clc}
\hline Solution & \multicolumn{2}{c}{ Means \pm SD } \\
\hline Saline & $1.442 \pm 0.590$ & a \\
Hypochlorite & $0.626 \pm 0.425$ & b \\
Chlorhexidine & $0.309 \pm 0.254$ & c \\
\hline
\end{tabular}

Means followed by different letters differed at the $5 \%$ level of significance ( $\mathrm{p}<$ 0.05) using Tukey's test.

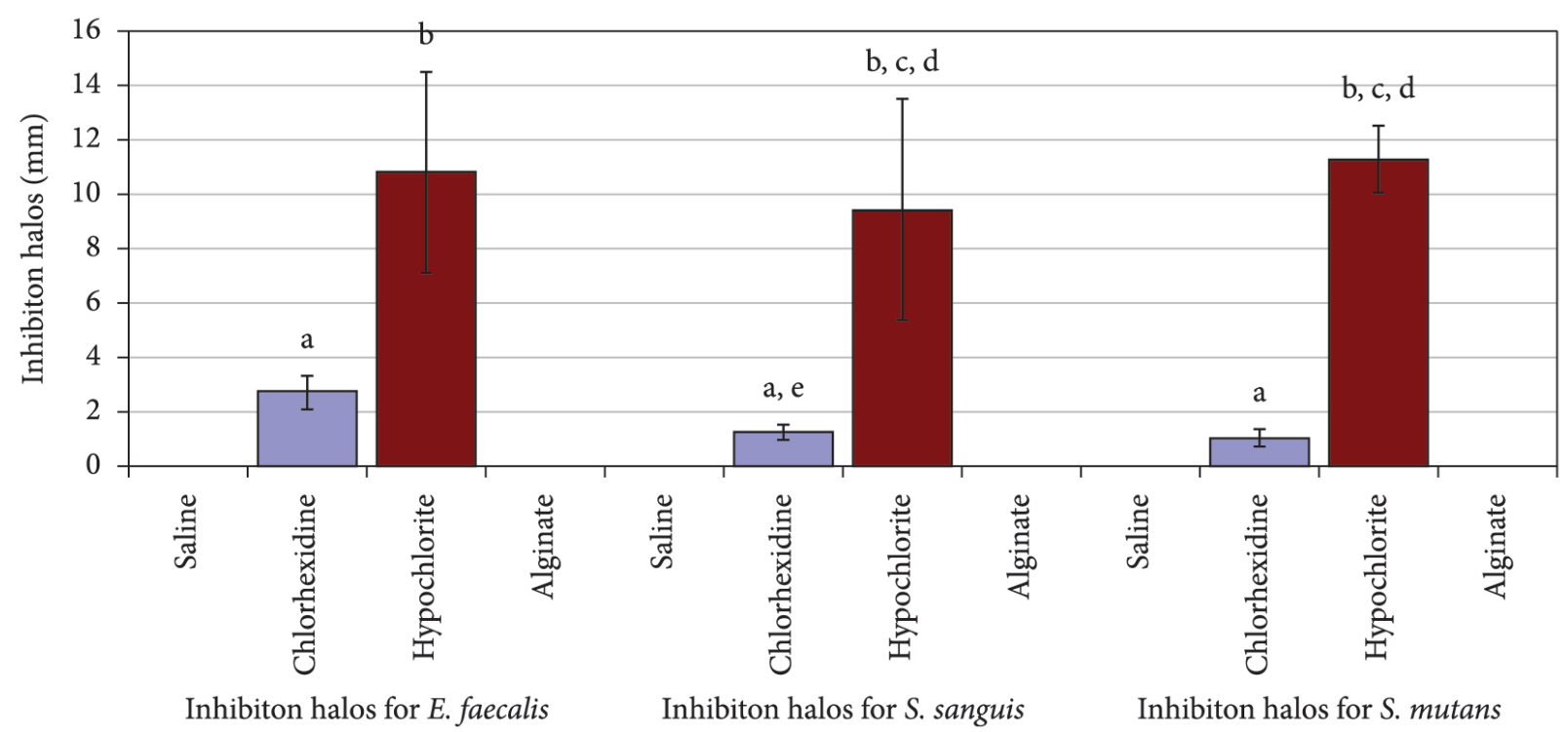

Figure 3. Graph of mean inhibition halos for each solution in relation to the microorganisms. Groups identified by the same letter were not significantly different from each other. 


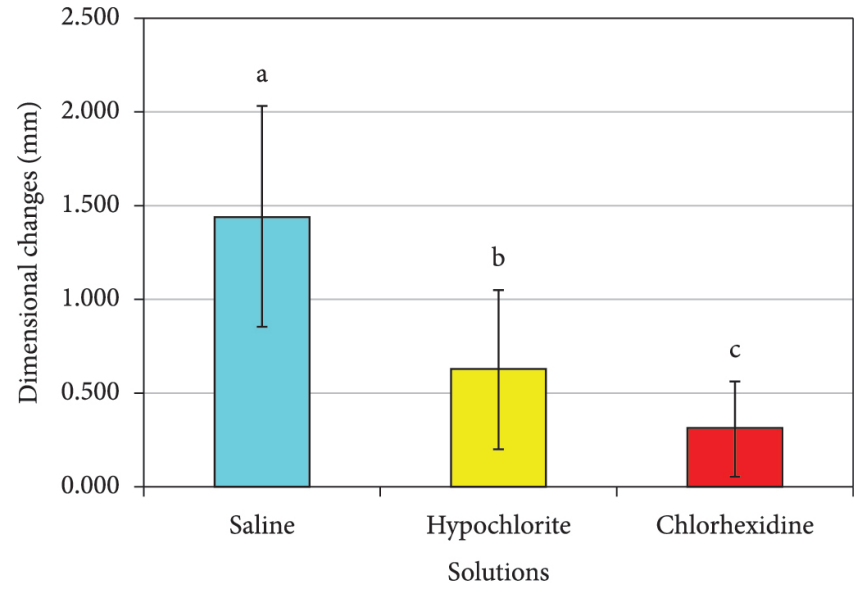

Figure 4. Graph of the mean values and standard deviations of the dimensional changes $(\mathrm{mm})$ for each solution. There was a significant difference between values indicated with different letters, using Tukey's test $(\mathrm{p}<0.05)$.

a moulding material that is highly susceptible to contamination and difficult to disinfect.

The clinical procedure is to wash the mould in running water for 20 seconds to remove saliva, blood and debris ${ }^{21,22}$. In the present study, after washing the moulds, two samples were made from different sites of each mould; the sampled areas were divided into right and left, both using the corresponding teeth (incisor to canine), gum and palate regions. Two samples from each mould were required as positive controls to show the efficiency of the solutions and verify whether the moulds had been disinfected ${ }^{19}$. Thus, identical conditions of microorganism retention in the moulds and casts were available.

In an in vitro study conducted by Tebrock et al..$^{23}$ (1989), only the control group sample showed contamination; a hypochlorite group showed no microorganism growth. This finding differs from the results of the current in vivo study, where there was growth in all samples from the control group and no inhibition in the entire $1 \%$ sodium hypochlorite group. These current results indicate that there was no significant difference in disinfection irrespective of the solution used.

Research by Schutt ${ }^{24}$ (1989) found that the presence of a disinfectant in the plaster mix promoted the complete disinfection of the moulds and casts, while all mould samples filled with plaster without disinfectant contained microorganisms. This finding contradicts the findings of the current study, where significant microbial growth was not seen in the plaster casts, irrespective of whether the substance used to handle them had antiseptic action. It is probable that factors unfavourable to the existing microorganisms in those contaminated moulds caused the microorganisms to not grow as expected; this theory does not indicate that all microorganisms would undergo the same process because effectiveness is directly related to microorganism pathogenicity. These results are restricted to the microorganisms used in this study, which were aerobic and facultative anaerobes. These results demonstrate the need for additional studies on the behaviour of various microorganisms that have different growth needs.
To supplement the in vivo study, and with the intention of determining the actual effect of disinfectant solutions on the microorganisms present in the oral cavity, the same substances that were tested in the clinical study were tested in vitro. The effect of these substances on three well-known oral microbiota microorganisms, S. mutans, S. sanguis and E. faecalis, was assessed.

In this study, after 24 hours, the $1 \%$ sodium hypochlorite had a higher disinfectant action than the $4 \%$ chlorhexidine gluconate for all microorganisms, and there was no significant difference in the size of the formed halo if the microorganism was varied and kept in the same solution. The finding that the hypochlorite formed a larger inhibition halo than the chlorhexidine is because the bactericidal action of the former is greater than that of the latter solution ${ }^{1,19}$. Even at a $1 \%$ concentration level, sodium hypochlorite is a more powerful disinfectant than a $4 \%$ concentration level of chlorhexidine. However, the incorporation of $4 \%$ chlorhexidine in the manipulation of type IV plaster may still be indicated because of its known antimicrobial activity and the minimal dimensional alterations observed in the obtained casts.

This in vitro microbiological test showed that both $1 \%$ sodium hypochlorite and $4 \%$ chlorhexidine have an antimicrobial action; however, saline, Durone plaster and Jeltrate Plus alginate did not have antimicrobial action. Therefore, in the in vivo test, the finding that there was no significant appearance of CFU in the control group (saline) does not suggest that there was an inhibition of microbial growth. This in vitro study validates the in vivo study, as it showed that even though $1 \%$ sodium hypochlorite and $4 \%$ chlorhexidine had a disinfecting action, conditions unfavourable to microbial growth were instrumental in the absence of microbial growth in the in vivo study.

Several studies ${ }^{4,9,14-17}$ have evaluated the effect of disinfectant substances on the mechanical properties of plaster. However, the majority of these studies examined the properties of plaster casts obtained after disinfecting the moulds with spray or by immersion, not by incorporating the disinfectant into the plaster solution. The present study investigated the existence of dimensional changes in the obtained casts by incorporating two disinfectant substances (1\% sodium hypochlorite and $4 \%$ chlorhexidine) into the type IV plaster mix.

Despite the need to evaluate whether disinfectants cause dimensional changes in casts, which may lead to impairments in prosthetic results, there are few studies in the literature. Among these few studies, Minagi et al..$^{25}$ (1987) is noteworthy. These authors evaluated linear dimensional changes between the metal pins fixed in the casts after immersion of alginate moulds for up to 180 minutes and showed that $2 \%$ glutaraldehyde was the ideal disinfectant solution for alginate. With the same objective, Pavarina et al. ${ }^{26}$ (1998) observed that dimensional changes were not significant in alginate moulds that had been immersed in $2 \%$ glutaraldehyde; however, the dimensional change was significant when a solution of $0.5 \%$ sodium hypochlorite was used for up to 30 minutes. Santos Júnior et al. ${ }^{4}$ (2001), Santos, Jorge ${ }^{7}$ (2001) and Zanet et al..$^{13}$ (2003) showed that a mould could be disinfected for 
10 minutes in a solution of $0.5 \%$ sodium hypochlorite without clinical compromise and that this technique could be used to obtain casts that do not require strict dimensional accuracy. The results of Merchant et al. ${ }^{5}$ (1984) and Sarma, Neiman ${ }^{27}$ (1990) corroborate these findings. The occurrence of dimensional changes in the studies cited above can be attributed to the fact that alginate is a material with poor dimensional stability that undergoes an imbibition process when immersed in the tested disinfectant substances.

Pavarina et al. ${ }^{26}$ (1998) used a metal matrix and individual moulds to create the mouldings evaluated in their study, and their results indicated significant dimensional changes when alginate was used. This finding could be explained by the lack of standardisation in the insertion axis of the mould, as the mould was held in a vice and the matrix was seated by hand. The present study corroborates these findings. Care was taken to ensure that the insertion axis of the mould and the force used during the moulding would be standardised during the experiment. To standardise the insertion axis, the matrix was kept on a vertical movable rod of a removable denture liner, and the mould was secured to the platform of this rod. The force used during moulding was standardised by the shape of the mould, which only allowed the insertion of the matrix to a specific depth. Based on this information, it is argued that the differences observed in this study must have been due to the solutions used during manipulation of the plaster.

Several authors have used distilled water as a control during their experiments on dimensional changes in plaster casts $^{8,14,17}$. In the current study, saline was used as the control substance. This choice is justified by the fact that saline is a sterile and stable solution that was also used in this study's microbiological evaluation. Analysis of the statistical results, however, indicated that this solution did not show the expected inert behaviour; there was a greater change in this group than in the tested disinfectant groups. One explanation for this finding may be the occurrence of a reaction between the sodium chloride in the saline and calcium sulphate dihydrate
$\left(\mathrm{CaSO}_{4} \cdot 2 \mathrm{H}_{2} \mathrm{O}\right)$. For this reason, the use of distilled water as a control is recommended.

Soares, Ueti ${ }^{9}$ (2001) reported no statistically significant differences in the obtained casts. In Lucas et al. ${ }^{16}$ (2009), where disinfectants were also incorporated during the manipulation of the plaster, a chlorhexidine group showed changes similar to the control group; this finding is similar to the results of the current study, in which a clinically insignificant dimensional change was found in the $4 \%$ chlorhexidine group. In the present study, changes were also observed in the group manipulated with $1 \%$ sodium hypochlorite when evaluating the distances between the centres of the cylinders, confirming the findings of Ivanovski et al. ${ }^{19}$ (1995), Scaranelo et al. ${ }^{28}$ (2004) and Lucas et al. ${ }^{16}$ (2009).

According to ADA specification number $25^{29}$, the percentage of acceptable dimensional changes in type IV plaster is $0.10 \%$. In the current study, the $4 \%$ chlorhexidine solution was the only solution that conformed to this specification, with a change of $0.06 \%$; hypochlorite caused a $1.5 \%$ dimensional change.

Considering the lack of other studies using the same methodologies, additional physical properties, such as microhardness and surface roughness, as well as other moulding materials and disinfectant substances, could be tested using the methodology employed in this study. However, simple and feasible disinfection measures that do not compromise the final result of the work should be adopted, as there is an immediate contamination of materials that are used in the patient's oral cavity.

\section{CONCLUSION}

1. Moulds obtained from the oral cavity of dental patients are contaminated.

2. The incorporation of a disinfectant substance in place of water when making the cast reduces the working time of the professional because disinfection is performed during the plaster setting time.

3. The most effective disinfectant solution introduced was $4 \%$ chlorhexidine, due to its observed antimicrobial action and clinically insignificant dimensional changes.

\section{REFERENCES}

1. Maranhão KM, Lopes TC, Esteves RA. Biossegurança em prótese dentária: proposta de protocolo. Parte II. PCL Rev Ibero-Amer Prót Clín \& Lab. 2006; 8(40): 178-81.

2. Rowe AHR, Forrest JO. Dental impressions. The probability of contamination and a method of disinfection. Br Dent J. 1978; 145(6): 184-6. http://dx.doi.org/10.1038/sj.bdj.4804140. PMid:359005

3. Pavarina AC, Machado AL, Giampaolo ET, Vergani CE. Infecção cruzada entre o consultório odontológico e o laboratório via próteses contaminadas. PCL Rev Bras Prót Clín \& Lab. 1999; 1(1): 74-8.

4. Santos Júnior GC, Bastos LGC, Rubo JH. Avaliação das propriedades mecânicas do gesso tipo IV submetido a métodos de desinfecção. Parte 1 - resistência à compressão e à tração diametral. Rev Fac Odontol Bauru. 2001; 9(1/2): 87-92.

5. Merchant VA, McNeight MK, Ciborowski CJ, Molinari JA. Preliminary investigation of a method for disinfection of dental impressions. J Prosthet Dent. 1984; 52(6): 877-9. http://dx.doi.org/10.1016/S0022-3913(84)80024-4. PMid:6439853

6. Souza JPB, Grecca KAM, Silva W Jr, Duarte ER. Desinfecção e esterilização de materiais de moldagens. PCL. 2001; 3(14): 298-303.

7. Santos EM, Jorge AOC. Desinfecção de moldes de hidrocolóide irreversível e modelos de gesso com hipoclorito de sódio: eficiência e estabilidade dimensional. Rev Odontol UNESP. 2001; 30(1): 107-19. 
8. Garcia AR, Sousa V, Pellizzer EP, Zuim PRJ, Passos CLA. Alterações dimensionais produzidas em modelos de gesso decorrentes da imersão do molde de alginato em soluçãos desinfetante. Rev Odontol UNESP. 1995; 24(2): 271-80.

9. Soares CR, Ueti M. Influência de diferentes métodos de desinfecção química nas propriedades físicas de troquéis de gesso tipo IV e V. Pesqui Odontol Bras. 2001; 15(4): 334-40. http://dx.doi.org/10.1590/S1517-74912001000400011. PMid:11787322

10. Ferrucio M, Ferrucio E, Pereira JLN, Bley Sobrinho J. Estabilidade dimensional dos materiais de impressão desinfetados por imersão e por spray. PCL. 2001; 3(12): 133-6.

11. Santos FS, Scannavino FLF, Martins AT, Oliveira SC, Dias AP, Rodrigues RV. Conhecimento de acadêmicos em Odontologia sobre a desinfecção de moldes de hidrocolóide irreversível. Rev Odonto Ciênc. 2008; 23(4): 371-4.

12. Osório AF, Fatturi CC, Poisl MI, Samuel SMW. Avaliação da eficácia de agentes químicos na desinfecção de moldes de alginato. R Fac Odontol Porto Alegre. 1998; 39(1): 17-9.

13. Zanet CG, Imai MA, Tango RN, Pasin IM, Kimpara ET. Efeitos de desinfetantes sobre moldes de hidrocolóide irreversível. Rev Paul Odontol. 2003; 25(3): 14-7.

14. Abdelaziz KM, Combe EC, Hodges JS. The effect of disinfectants on the properties of dental gypsum, part 2: surface properties. J Prosthodont. 2002; 11(4): 234-40. http://dx.doi.org/10.1111/j.1532-849X.2002.00234.x. PMid:12501136

15. Scaranelo RM, Bombonatti PE, Rister RP, Bombonatti R, Bombonatti JFS. Efeito de soluções desinfetantes cloradas na resistência à compressão e dureza superficial dos gessos. PCL Rev Ibero-Am Prót Clín Laboratorial. 2004; 6(30): 159-65.

16. Lucas MG, Ribeiro JAR, Butignon LE, Arioli Filho JN, Ribeiro JGR. Efeito da incorporação de hipoclorito de cálcio em gesso tipo III sobre a estabilidade dimensional, resistência à tração diametral e a compressão. Ciênc Odontol Bras. 2009; 12(1): 63-9.

17. Lucas MG, Arioli-Filho JN, Nogueira SS, Batista AU, Pereira RP. Effect of incorporation of disinfectant solutions on setting time, linear dimensional stability, and detail reproduction in dental stone casts. J Prosthodont. 2009; 18(6): 521-6.; published online April $21,2009$. http://dx.doi.org/10.1111/j.1532-849X.2009.00466.x. PMid:19432758

18. Brace ML, Plummer KD. Practical denture disinfection. J Prosthet Dent. 1993; 70(6): 538-40. http://dx.doi.org/10.1016/00223913(93)90268-S. PMid:8277443

19. Ivanovski S, Savage NW, Brockhurst PJ, Bird PS. Disinfection of dental stone casts: antimicrobial effects and physical property alterations. Dent Mater. 1995; 11(1): 19-23. http://dx.doi.org/10.1016/0109-5641(95)80004-2. PMid:7498603

20. Samaranayake LP, Hunjan M, Jennings KJ. Carriage of oral flora on irreversible hydrocolloid and elastomeric impression materials. J Prosthet Dent. 1991; 65(2): 244-9. http://dx.doi.org/10.1016/0022-3913(91)90169-W. PMid:2051359

21. ADA Council on Scientific Affairs and ADA Council on Dental Practice. Infection control recommendations for the dental office and the dental laboratory. J Am Dent Assoc. 1996; 127(5): 672-80. http://dx.doi.org/10.14219/jada.archive.1996.0280. PMid:8642147

22. Mitchell DL, Hariri NM, Duncanson MG Jr, Jacobsen NL, McCallum RE. Quantitative study of bacterial colonization of dental casts. J Prosthet Dent. 1997; 78(5): 518-21. http://dx.doi.org/10.1016/S0022-3913(97)70069-6. PMid:9399197

23. Tebrock OC, Engelmeier RL, Mayfield TG, Adams HJU. Managing dental impressions and casts of patients with communicable diseases. Gen Dent. 1989; 37(6): 490-5. PMid:2700981.

24. Schutt RW. Bactericidal effect of a disinfectant dental stone on irreversible hydrocolloid impressions and stone casts. J Prosthet Dent. 1989; 62(5): 605-7. http://dx.doi.org/10.1016/0022-3913(89)90088-7. PMid:2607482

25. Minagi S, Yano N, Yoshida K, Tsuru H. Prevention of acquired immunodeficiency syndrome and hepatitis B. II: Disinfection method for hydrophilic impression materials. J Prosthet Dent. 1987; 58(4): 462-5. http://dx.doi.org/10.1016/0022-3913(87)90277-0. PMid:3478478

26. Pavarina AC, Bussadori CMC, Cucci ALM, Vergani CE, Giampaolo ET. Influência da desinfecção de moldes na alteração dimensional de modelos de gesso. Rev Odontol UNESP. 1998; 27(2): 381-91.

27. Sarma AC, Neiman R. A study on the effect of disinfectant chemicals on physical properties of die stone. Quintessence Int. 1990; 21(1): 53-9. PMid:2115681.

28. Scaranelo RM, Bombonatti PE, Rister RP, Bombonatti R, Bombonatti JFS. Influência de soluções desinfetantes cloradas no tempo e na expansão de presa de dois tipos de gesso. Rev Fac Odontol Aracatuba. 2004; 25(1): 44-8.

29. Council of Dental Materials. Instruments and Equipment. Revised American National Standards Institute. American Dental Association Specification No. 25 for dental gypsum products. J Am Dent Assoc. 1981; 102: 351.

\section{CONFLICTS OF INTERESTS}

The authors declare no conflicts of interest.

\section{${ }^{*}$ CORRESPONDING AUTHOR}

Patrícia Lins Azevedo do Nascimento, Rua XV de Novembro, 28, São José, 55295-230 Garanhuns - PE, Brasil, e-mail: patricialanascimento@hotmail.com 